\title{
Signet Ring Cell Neuroendocrine Tumor
}

Sabbah $M^{1}{ }^{*}$, Trad D², Bellil N², Jouini $\mathbf{R}^{2}$, Ouakaa $\mathrm{A}^{2}$, Elloumi $\mathbf{H}^{2}$, Bibani $\mathrm{N}^{2}$, Gargouri $\mathrm{D}^{2}$

${ }^{1}$ Departement of gastroenterology. Habib Thameur Hospital

${ }^{2}$ Departement of pathology. Habib Thameur Hospital

*Corresponding author: Sabbah Meriam, Departement of gastroenterology. Habib Thameur Hospital. Email: sabbah_meriam@yahoo.fr Received Date: November 8, 2019; Accepted Date: November 12, 2019; Published Date: November 29,2019

Citation: Sabbah M, Trad D, Bellil N, Jouini R, Ouakaa A. et al. (2019) Signet ring cell neuroendocrine tumor. Surgical Case Reports and Images, 2(1); Doi:10.31579/JSCR/2019/009

Copyright: (C2019. Sabbah Meriam. This is an open-access article distributed under the terms of the Creative Commons Attribution License, which permits unrestricted use, distribution, and reproduction in any medium, provided the original author and source are credited.

\section{Case report}

A 63 years old woman with history of diabetes and hypertension, presented for bone pain. Pelvic X Ray showed multiple osteoconsensant lesions of the iliac wings, the sacrum and the femurs (figure 1). CT scan objectified multiple hepatic metastases with a laterorectal mass (figure 2). Colonoscopy showed aspect of extrinsic compression. Endoscopic ultrasound objectified a rectal mucosal lesion of $5 \times 3,5$ centimeters appearing in contact with the prostate (figure 3). Histologically, hepatic biopsy confirmed a tumor proliferation that was made of two architectural aspects independent cells, and trabeculolobular classical endocrine architecture with expression of synaptophysin on immunochemistry (figure 4).

\section{Figures}

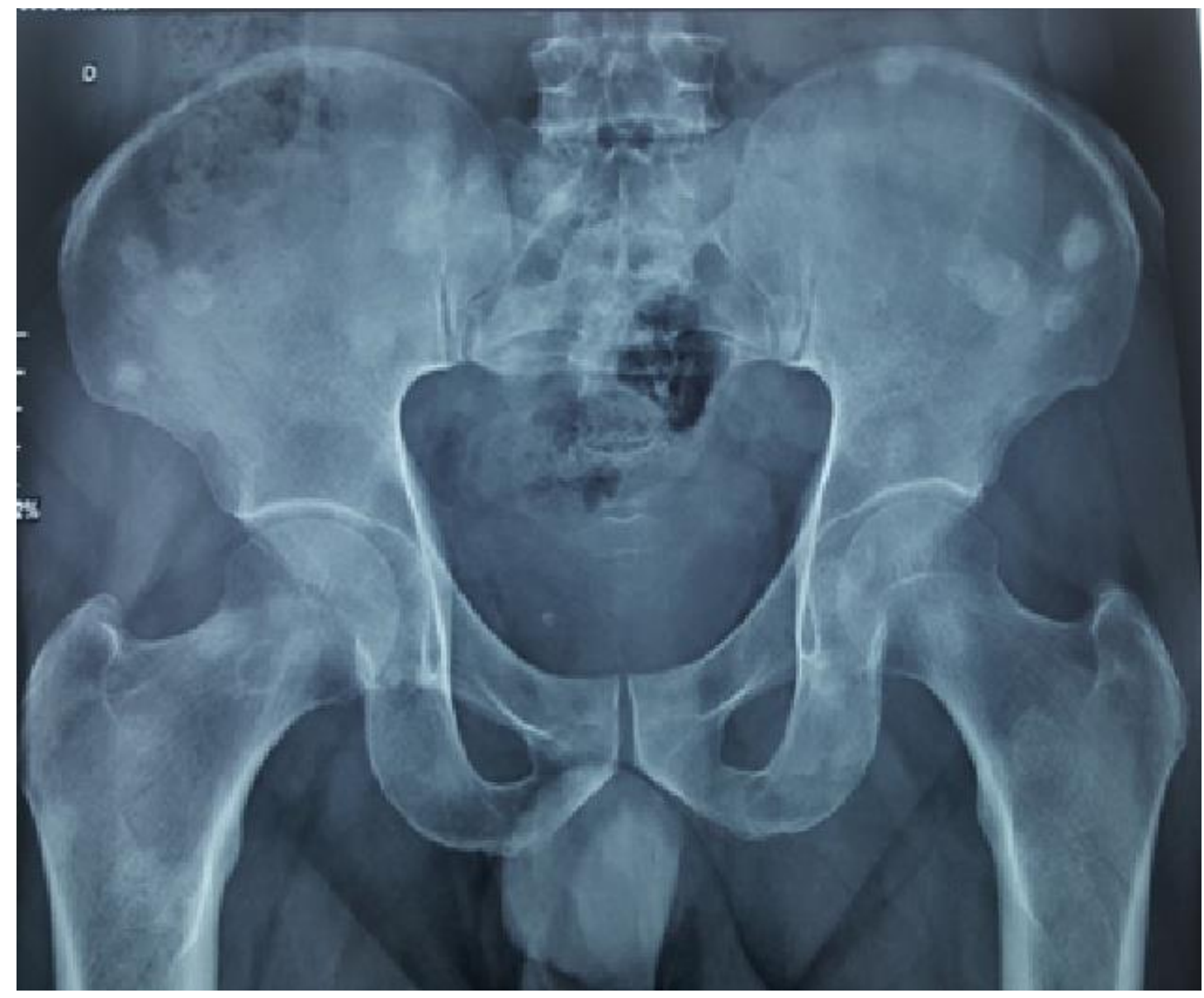




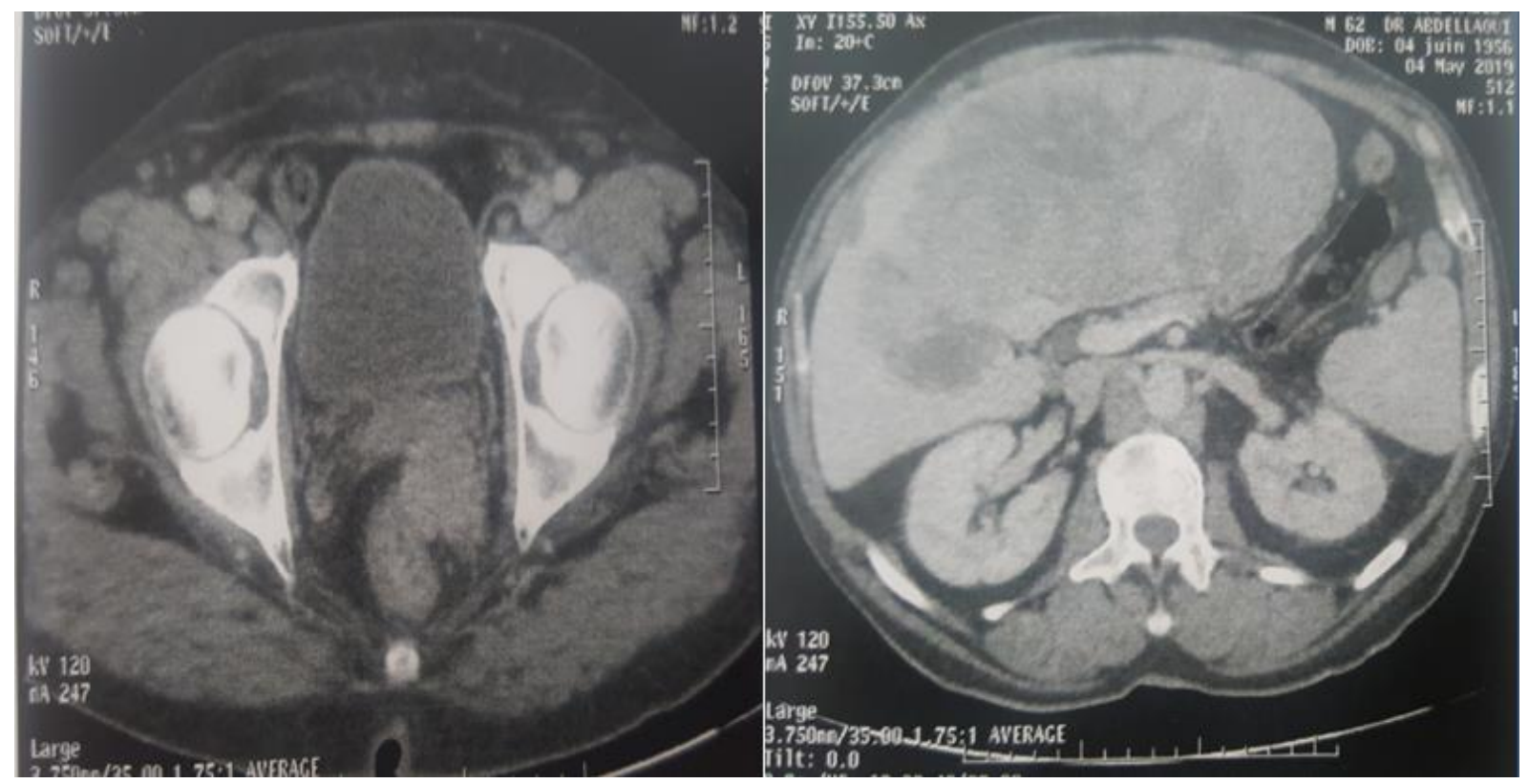

Figure 2: CT scan objectified multiple hepatic metastases with a laterorectal mass

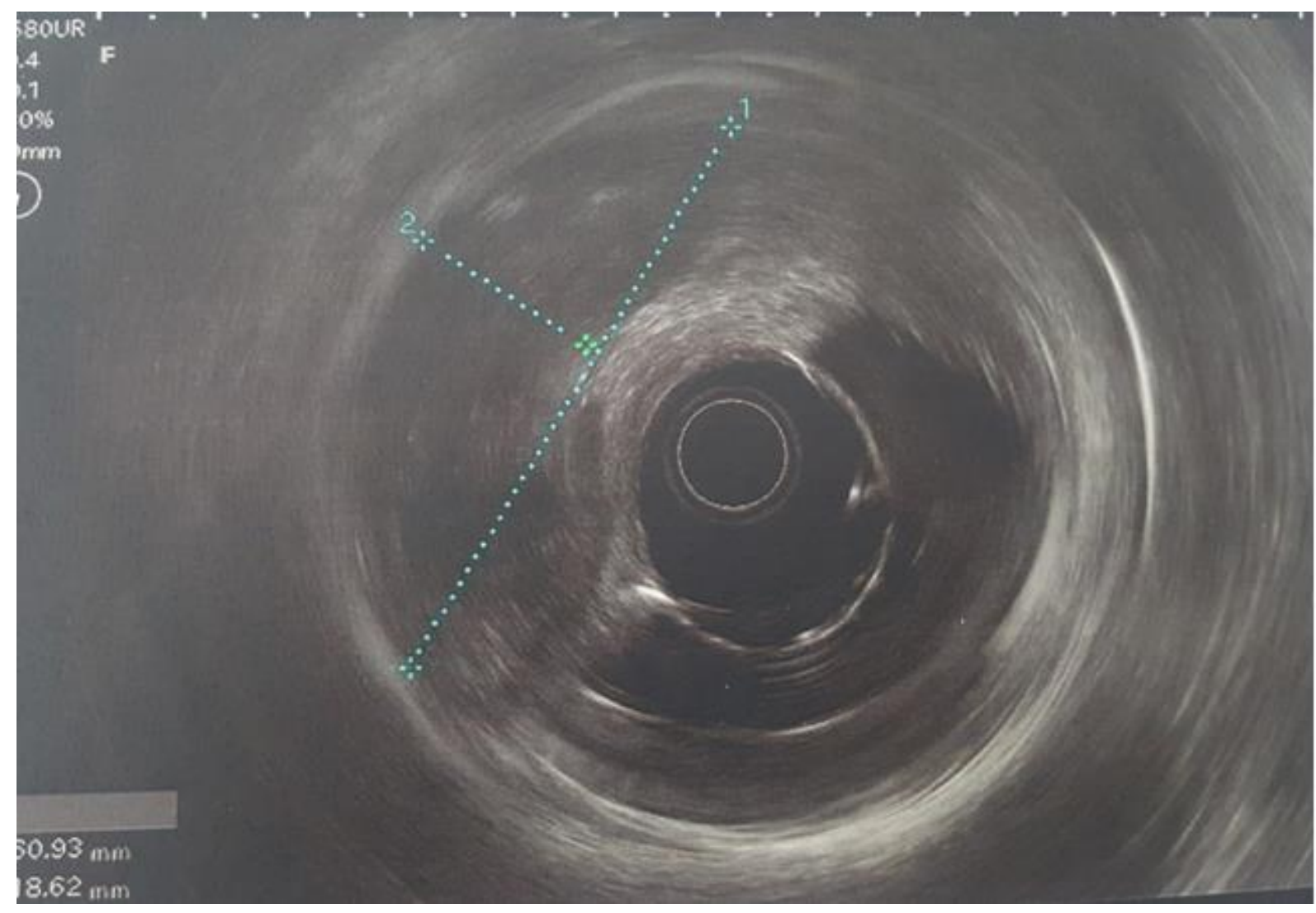

Figure 3: Endoscopic ultrasound objectified a rectal mucosal lesion of 5x3, 5 centimeters appearing in contact with the prostate 

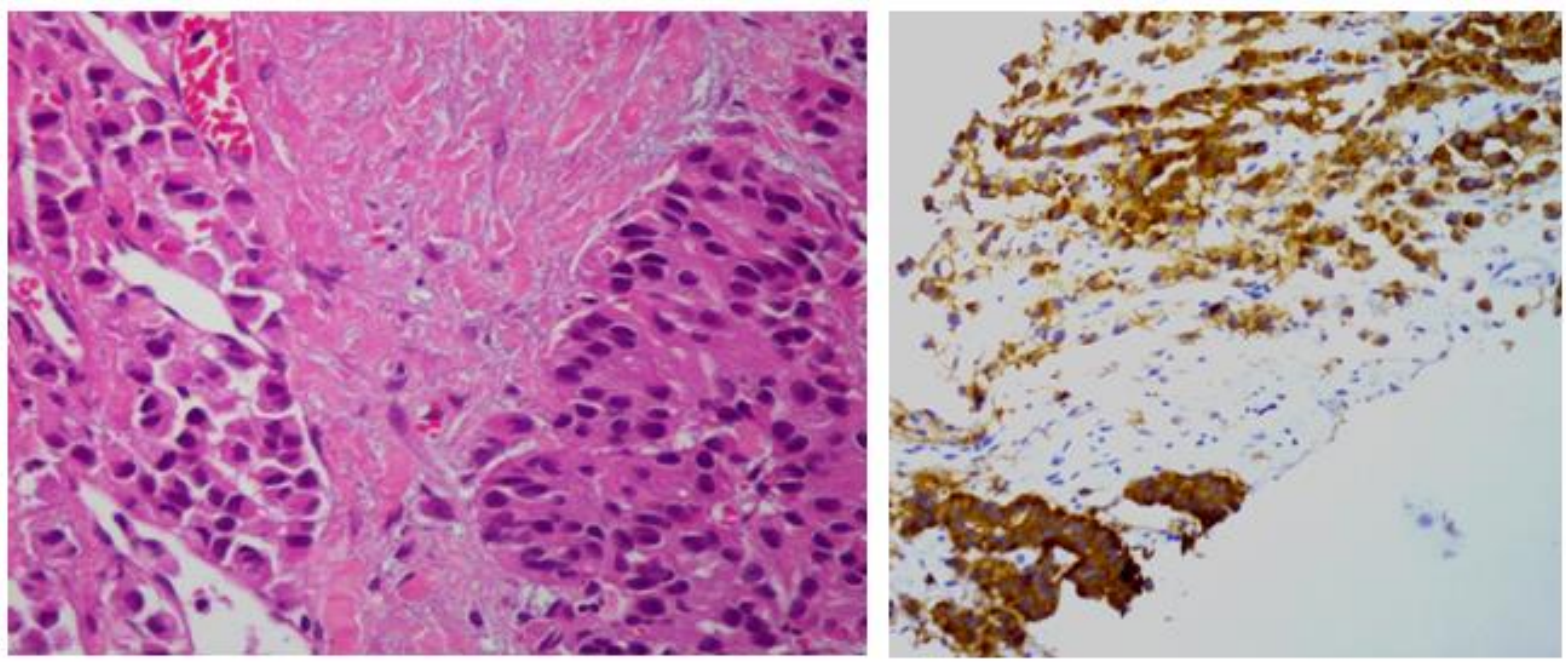

Figure 4: hepatic biopsy showing a tumor proliferation that was made of two architectural aspects independent cells, and trabeculolobular classical endocrine architecture with expression of synaptophysin on immunochemistry

\section{References}

1. Haq S, Batra VV, Majumdar K, Javed A, Agarwal AK.et al (2015) Signet ring cell neuroendocrine tumor liver with mesenteric metastasis: Description of a rare phenomenon, with literature review J Cancer Res Ther., 11(3):658.

2. Madakshira MG, Radotra BDn Singh V. Indian J Pathol Microbiol. (2019) Signet ring: A rare morphology of metastatic neuroendocrine tumor. (62): 335-336.

3. Shaieb W, Krishna K, Kim S, Godman M, Rock J, Chen Z and al. (2016) Appendiceal Neuroendocrine, Goblet and SignetRing Cell Tumors: A Spectrum of Diseases with Different
Patterns of Presentation and Outcome. Cancer Res Treat. 48 (2): 596-604

4. He F, Nie L. (2019) Synchronous neuroendocrine tumor and signet-ring cell carcinoma in the stomach.Clinics and research in hepatology and gastroenterology. (43): 505-507.

5. Korphaisarn, K., Morris, V., Davis, J.S and al. (2019) Signet ring cell colorectal cancer: genomic insights into a rare subpopulation of colorectal adenocarcinoma. $\mathrm{Br} J$ Cancer (121), 505-510 